\title{
Sponsor hunt divides geosciences union
}

Talks about approaching the oil company ExxonMobil as a possible meeting sponsor are raising tempers at the European Geosciences Union (EGU) in Strasbourg, France. Some scientists fear that sponsorship from the company would damage the integrity of the organization.

The EGU council argued over its options at a meeting on 12 October, but made no decision as to which companies should be approached. But Nature has learned that ExxonMobil is likely to be on a list of possible sponsors that the council has asked John Ludden, the EGU's vice-president, to compile in the upcoming weeks.

The 25-member council did agree that it would need to discuss and agree on potential sponsors before they were approached. If it could not reach a consensus, an ethics committee - the members of which will be appointed shortly - would weigh in.

ExxonMobil, which last year reported record earnings of US $\$ 39.5$ billion, donates tens of millions of dollars every year to universities and scientific organizations, including the American Geophysical Union

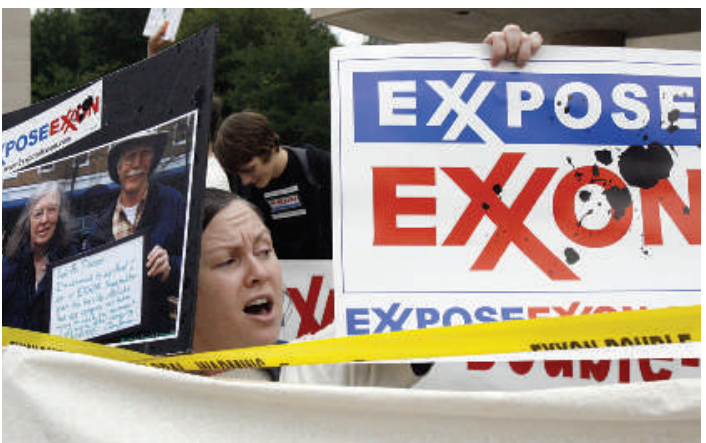

ExxonMobil is one of several companies being considered as a sponsor for scientific meetings.

(AGU) in Washington DC. However, the company has been criticized in the past for also funding climate sceptic groups that critics say attempt to cloud the scientific understanding of climate change and delay action against global warming.

The company has now stopped funding some of these groups, such as the Competitive Enterprise Institute in Washington DC. And its 2006 corporate citizen report states that "it is prudent to develop and implement strategies" to deal with rising greenhousegas emissions.

Unlike its American sister organization, the EGU - which launched in 2002 as a merger of two other groups - has not accepted funding from private sponsors. ExxonMobil did fund a student lunch during the EGU's 2006 meeting in Vienna, Austria, but the event, which was to help students make contact with potential employers, was not an official part of the conference.

The EGU's annual meetings, which attract

some 8,000 scientists, generate most of the group's income. But the high registration fee up to $€ 400$ (US\$577) next year - is not affordable for many scientists and students from poorer countries. "We're not going to go bankrupt," says Ludden. "But in order to attract more scientists from Africa and eastern Europe we really should start looking for suitable sponsors."

Like many geologists, for whom oil companies are the main non-academic employers, Ludden says that he has no problems with accepting funds from the oil industry.

(

"We should be open to various types of interaction with industry."

He hopes that introducing sponsors will raise several hundred thousand euros per year for student sponsorship, teachers' education and for underwriting the costs of new journals.

Tim Killeen, president of the AGU, says that issues of sponsorship there "have been a topic of lively discussion for many years". In the European group, dissent is led mainly by climate scientists and those outside the solid-earth community. "Although we should be open to various types of interaction with industry, we shouldn't approach certain companies just because they're free with money," says Hermann Held, chair of the EGU's division for energy, resources and the environment.

If sponsorship were to move forward, it would be unlikely to be in place for the 2008 meeting in Vienna, says Ludden.

"It's a delicate issue," says Gerald Ganssen, the EGU's president. "We'll take all necessary means to solve this internally to avoid the risk of splitting the EGU."

Quirin Schiermeier

\section{Economical and Efficient}
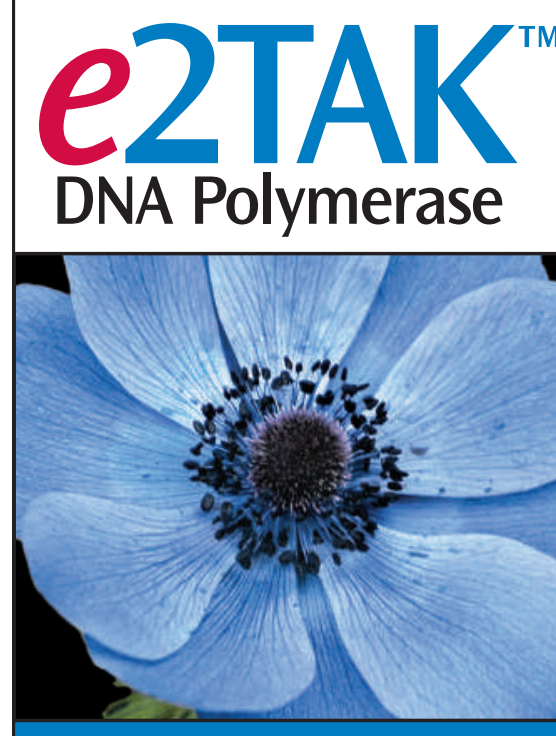

- Economical Alternative to Taq

- More Sensitive than Taq

- Higher Yield than Taq

- Includes 5X Buffer and High Purity dNTPs

Note: PCR products generated with e2TAK will contain blunt ends.

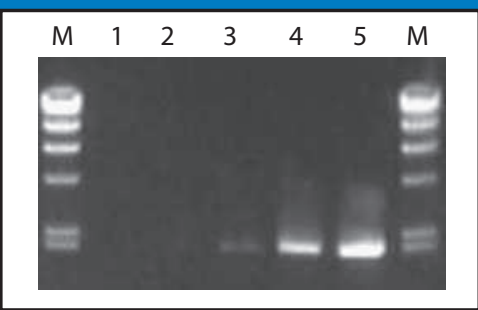

Amplification of a 2 kb $\lambda$-DNA Fragment with e2TAK'M DNA Polymerase. Excellent sensitivity and yield are observed when amplifiying a $2 \mathrm{~kb} \lambda$ fragment. Lane 1: No template, Lane 2: $100 \mathrm{fg}$, Lane 3: $1 \mathrm{pg}$, Lane 4:10 pg, Lane 5: 100 pg Lane M: $\lambda$-Hind III digest

$$
\begin{aligned}
& \text { e2TAK }{ }^{T M} \text { is a trademark of Takara Bio Inc, Inc. } \\
& \text { Sold in the United States only. }
\end{aligned}
$$

Try a Free Sample Today!

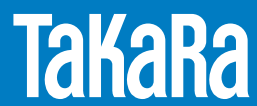

www.takarabiousa.com 888-251-6618 